\title{
DAYA DUKUNG EKOLOGI UNTUK BUDIDAYA IKAN KAKAP DALAM KERAMBA JARING APUNG, STUDI KASUS DI PERAIRAN BIAK-NUMFOR
}

\author{
Ariani Andayani\#, Wartono Hadie, dan Ketut Sugama \\ Pusat Riset Perikanan \\ Gedung BRSDMKP II, JI. Pasir Putih II, Ancol Tmur, Jakarta Utara 14430 \\ (Naskah diterima: 17 Januari 2018; Revisi final: 28 M ei 2018; Disetujui publikasi: 28 Mei 2018)
}

\begin{abstract}
ABSTRAK
Kabupaten Biak-Numfor merupakan salah satu lokasi yang ditetapkan sebagai Sentra Kelautan dan Perikanan Terpadu (SKPT), yang memiliki potensi untuk pengembangan budidaya laut, sehingga perlu dilakukan kajian kesesuaian lokasi dan daya dukung lingkungannya. Penelitian ini bertujuan untuk mengkaji kesesuaian perairan dan estimasi daya dukung lingkungan (ekologi) untuk pengembangan budidaya ikan kakap (Lates calcarifer). Kajian ini dilakukan di dua lokasi yaitu Pulau Nusi dan Teluk Urfu. Pengumpulan data primer dilakukan melalui survai lapangan dan pengumpulan data sekunder melalui Dinas terkait. Data survai lapangan yang dikumpulkan meliputi: arus, kedalaman, pH, suhu, salinitas, dissoloved oxygen (DO), amonia, nitrit, nitrat, fosfat, total suspended solid (TSS), dan kecerahan. Data sekunder yang dikumpulkan antara lain: Peta RBI dan data spasial dari Rencana Zonasi Wilayah Pesisir dan Pulau-Pulau Kecil RZWP3K Kabupaten Biak-Numfor 2015. Analisis kesesuaian perairan dilakukan dengan perangkat lunak Quantum GIS (QGIS). Analisis spasial berbasis raster. Hasil analisis kesesuaian perairan untuk budidaya ikan kakap dalam keramba jaring apung (KJA), di sekitar Pulau Nusi memiliki potensi yang sesuai seluas 324,11 ha dari total area seluas $2.643 \mathrm{ha}$, sedangkan di Teluk Urfu area yang sesuai seluas 0,247 ha dari total area $33 \mathrm{ha}$. Hasil perhitungan daya dukung ekologi, Teluk Urfu tidak direkomendasikan adanya kegiatan budidaya ikan, kenyataannya saat ini telah terpasang 12 lubang KJA. Sedangkan di Pulau Nusi potensi pengembangan budidaya laut khususnya ikan kakap cukup luas. Daya dukung ekologinya adalah 158 lubang KJA $(3 \mathrm{~m} \times 3 \mathrm{~m} \times 3 \mathrm{~m})$ dengan terget panen per lubang adalah $175 \mathrm{~kg}$.
\end{abstract}

KATA KUNCI: analisis spasial; daya dukung ekologi; pemilihan lokasi; QGIS

ABSTRACT: Ecological carrying capacity of seabass culture in cage, a case study in water of Biak-Numfor. By: Ariani Andayani, Wartono Hadie, and Ketut Sugama

Biak-Numfor Regency has been designated as one of the locations of Integrated Marine and Fisheries Center (SKPT). The region has the potential to be developed as mariculture area. Thus, it is necessary to determine the site suitability and calculate the environmental carrying capacity of the area for mariculture development. This study aimed to assess the site suitability and estimate the environmental carrying capacity (ecology) of the region waters for Asian seabass/ barramundi (Lates calcarifer) mariculture. The study was carried out in two locations: Nusi Island and Urfu Bay. Primary data were collected from a field survey and secondary data was gathered from the local fisheries extension office in Biak District. On-the-field measured parameters included: water current, depth, pH, temperature, salinity, dissolved oxygen, ammonia, nitrite, nitrate, phosphate, total suspended solids, and transparency. Secondary data collected from the local agency were: topographical maps of the region and vector-based spatial data from RZW P3K Biak-Numfor Regency. Site suitability analysis was donewith QGIS. Spatial analysis was based on GISraster environment. This study found that the suitable site for Asian seabass/barramundi floating net cages mariculture(FNC) was estimated around 324.11 ha and 0.247 ha for Nusi Island and Urfu Bay, respectively. Based on estimates of environmental carrying capacity (ecology), Urfu Bay is not recommended for fish culture despitethe study had found onefloating fish farm with 12 net cages operating in the area. In contrast, waters of Nusi Island Based has significantly higher ecological carrying capacity which is estimated able to hold 158 floating net cages $(3 \mathrm{~m} \times 3 \mathrm{~m} \times 3 \mathrm{~m})$ with the maximum holding density of $175 \mathrm{~kg}$ per cage.

\section{KEYWORDS: spatial analysis; ecological carrying capacity; site selection; QGIS}

\footnotetext{
\# \# Korespondensi: Pusat Riset Perikanan. Gedung BRSDM KP II,

Jl. Pasir Putih II, Ancol Tmur, Jakarta Utara 14430

Tel. + 622164700928

E-mail: arianiandayani@gmail.com
} 


\section{PENDAHULUAN}

Dalam Peraturan Menteri KP NOMOR 48/PERMEN$\mathrm{KP} / 2015$ diamanatkan bahwa salah satu program Kementerian Kelautan dan Perikanan (KKP) untuk mewujudkan Visi dan Misi KKP yaitu: Kedaulatan, Keberlanjutan, dan Kesejahteraan. Dalam mengimplementasikan program tersebut, maka dilakukan pembangunan Sentra Kelautan dan Perikanan Terpadu (SKPT) berbasis pulau-pulau kecil terdepan dan/atau kawasan perbatasan secara terintegrasi dan menyeluruh. Program tersebut penekanannya pada pembangunan sarana dan prasarana penunjang, serta sistem pengelolaan sumber daya perikanan, yang tidak hanya bertumpu pada penguatan sektor hilir (pengolahan). Pada sektor hulu adalah penyediaan bahan baku industri perikanan. Program SKPT ini mengarah pada optimalisasi usaha penangkapan ikan, pembudidayaan ikan, usaha tambak garam, serta pengolahan dan pemasaran hasil perikanan. Dengan demikian pelaku utama dan pelaku usaha kelautan dan perikanan akan mendapatkan keuntungan ekonomi (margin ekonomi) yang tinggi. Pada gilirannya akan meningkatkan kesejahteraan pelaku utama dan pelaku usahakelautan dan perikanan khususnya di pulau-pulau kecil dan/atau kawasan perbatasan yang merupakan bagian dari SKPT yang dicanangkan oleh Menteri Kelautan dan Perikanan.

Kementerian Kelautan dan Perikanan telah menetapkan 20 lokasi Pembangunan Sentra Kelautan dan Perikanan Terpadu (PSKPT) di pulau-pulau kecil dan kawasan perbatasan, yang ditetapkan melalui Keputusan Menteri (Kepmen) No. 51 Tahun 2016 tentang Penetapan Lokasi Pembangunan Sentra Kelautan dan Perikanan Terpadu di Pulau-Pulau Kecil dan Kawasan Perbatasan. Kabupaten Biak-Numfor, Provinsi Papua adalah salah satu lokasi yang ditetapkan sebagai PSKPT. Posisi geografis Biak cukup strategis dikembangkan dengan jalur penerbangan ke Hawai dan Palau, serta ke Jepang.

Dalam Permen KP tersebut disebutkan bahwa pembudidayaan ikan merupakan salah satu target pro gram yang akan dikembangkan. Pengembangan budidaya ikan menurut FAO (2010), telah beralih dari pendekatan konvensional ke pendekatan ekosistem (ecosystem approach to aquaculture/EAA). EAA adalah sebuah pendekatan budidaya berbasis ekosistem yang merupakan strategi terintegrasi antara kegiatan dalam ekosistem yang lebih luas seperti mengedepankan pembangunan berkelanjutan, ekuitas, dan ketahanan (resilient) yang saling terkait dalam sistem sosialekologi. Ada tiga sasaran utama dalam EAA yaitu: 1) memastikan kesejahteraan manusia; 2) memastikan kelestarian ekologi; dan 3) memfasilitasi pencapaian keduanya. Hasil utama yang diharapkan adalah: 1) Sektor budidaya yang benar-benar berkelanjutan dalam dimensi ekologi, ekonomi dan sosial dan; 2) Perubahan masyarakat pada tingkat pola pikir, sikap dan tindakan dalam usaha budidaya.

Tiga prinsip utama sebagai panduan dalam EAA menurut FAO (2010) adalah: 1) Pengembangan dan pengelolaan budidaya harus memperhitungkan jangkauan jasa dan fungsi ekosistem dan seharusnya tidak mengancam kelestarian; 2) Kegiatan budidaya harus meningkatkan kesejahteraan pembudidaya dan keadilan bagi seluruh pemangku kepentingan; dan 3) Kegiatan budidaya harus dikembangkan dalam konteks kebijakan dan sasaran sektor-sektor lainnya. Prinsip yang ketiga merupakan pengembangan multisektoral atau sistem perencanaan dan pengelolaan yang terintegrasi.

Penelitian ini belum mencakup secara keseluruhan apa yang dimaksud dalam EAA, namun merupakan salah satu hal penting sebelum dilaksanakannya kegiatan budidaya, yaitu pemilihan lokasi budidaya yang sesuai dengan memperhitungkan fungsi ekosistem. Hal ini untuk menunjang salah satu sasaran dalam EAA yaitu memastikan kelestarian ekologi. Pemilihan lokasi yang baik dan perhitungan daya dukung lingkungan dimaksudkan untuk mendukung pengembangan marikultur yang berkelanjutan.

Tujuan dari penelitian ini adalah mengkaji kelayakan lokasi untuk budidaya ikan kakap (Lates calcarifer) dan estimasi daya dukung ekologi di Pulau Nusi dan Teluk Urfu, Kabupaten Biak-Numfor.

\section{BAHAN DAN METODE}

\section{Pemilihan Lokasi Penelitian}

Pemilihan lokasi didasarkan pada dokumen yang telah ada sebelumnya dan diskusi dengan Dinas Kelautan dan Perikanan Kabupaten Biak-Numfor. Dokumen yang tersedia sebelumnya yaitu Rencana Zonasi Wilayah Pesisir dan Pulau-pulau Kecil (RZWP3K) tahun 2015 yang telah disusun oleh Pemda Kabupaten Biak Numfor, serta dengan memperhatikan Keputusan Menteri Kelautan dan Perikanan Republik Indonesia Nomor 62/kepmen-kp/2014 tentang rencana pengelolaan dan zonasi taman wisata perairan Kepulauan Padaido dan laut di sekitarnya di Provinsi Papua tahun 2014-2034.

Penelitian ini dilakukan di dua lokasi yaitu di Teluk Urfu, Kecamatan Yendidori dan di sekitar Pulau Nusi, Kecamatan Padaido, Kabupaten Biak-Numfor, Papua (Gambar 1). 


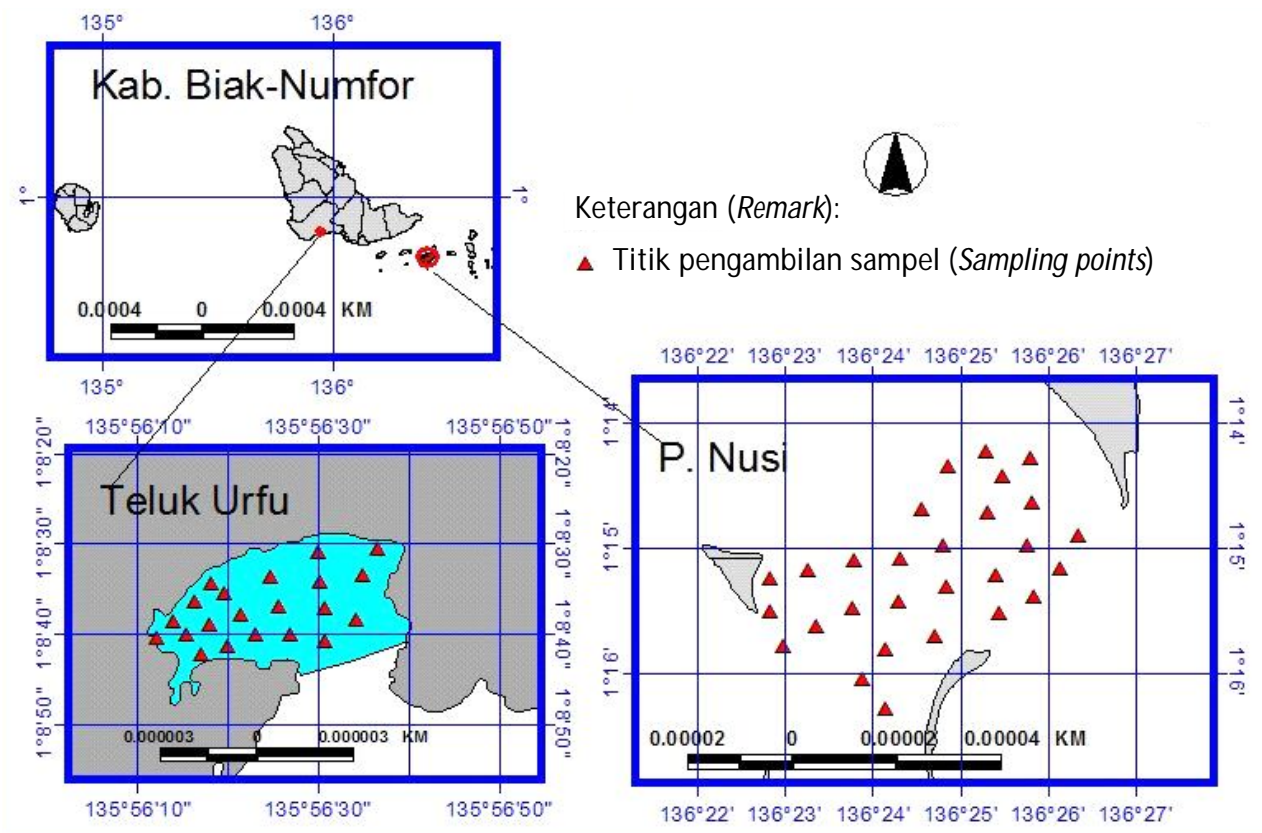

Gambar 1. Lokasi penelitian dan sebaran titik pengambilan sampel.

Figure 1. Study area and distribution of sampling points.

\section{Pemilihan Komoditas}

Komoditas yang dipilih dalam penelitian ini adalah ikan kakap putih. Dirjen Perikanan Budidaya mengatakan bahwa pangsa pasar ekspor ikan kakap putih lebih luas daripada ikan kerapu (Simorangkir, 2017). Teknologi budidaya ikan kakap telah berkembang dengan baik. Benih ikan kakap untuk budidaya telah diproduksi di Bali, Batam, Jawa Timur (Priyono et al., 2013) dan di Lampung (Akmal, 2011). Ikan kakap layak dibudidaya, selain memiliki karakteristik yang disukai konsumen antara lain: lembut dengan rasa ringan dan dalam bentuk tanpa tulang (fillet), ikan tumbuh cepat dan bersifat euryhaline atau dapat tumbuh pada salinitas 0 atau air tawar hingga salinitas tinggi atau air laut. Juvenilnya terlihat lebih cepat tumbuh pada salinitas yang rendah (Schipp et al., 2007). Menurut FAO, ukuran siap panen kakap putih dalah 350 gram sampai dengan $3 \mathrm{~kg}$ dalam waktu enam bulan hingga dua tahun.

\section{Pengumpulan Data}

Pengumpulan data dilakukan melalui survai lapangan pada Agustus 2016 dan akhir Oktober 2016 untuk Teluk Urfu, sedangkan untuk Pulau Nusi hanya dilaksanakan pada Agustus 2016. Data kualitas perairan diukur secara langsung dan diambil sampel untuk dianalisis di laboratorium (Proling IPB Bogor).

Data parameter kualitas perairan yang diukur secara langsung adalah kedalaman (batimetri), kecepatan arus, kecerahan perairan, $\mathrm{pH}$, suhu, salinitas, dan oksigen terlarut (DO). Dalam penelitian ini, alat yang digunakan untuk mengukur batimetri adalah Garmin Mapsounder 585, yang dipasang pada sisi luar lambung kapal dengan kecepatan kapal pada saat survei \pm 4 knot. Kecepatan arus diukur menggunakan current meter yang dicelupkan pada kedalaman 1-2 m selama \pm 5 menit pada setiap titik sampling. Kecerahan perairan diukur dengan menurunkan sacchi disk dengan tali yang telah diberi skala dalam satuan meter. Kemudian untuk parameter $\mathrm{pH}$, suhu, salinitas, dan DO diukur menggunakan YSI multiparameter sonde.

Beberapa parameter yang dianalisis di laboratorium adalah total suspended solid (TSS), nitrat, nitrit, fosfat, total $P$, dan amonia. Pengambilan sampel air untuk pengujian TSS, nitrat, nitrit, fosfat, dan amonia menggunakan alat Van Dorn water sampler pada kedalaman tiga meter. Khusus sampel untuk pengujian TSS, diambil satu liter air laut lalu disaring menggunakan vacuum pump dengan kertas saring berukuran pori 0,45 ìm. Kertas saring ini kemudian dilipat dan disimpan pada suhu dingin. Pengujian untuk parameter lainnya adalah dengan mengambil sampel air laut dengan volume satu liter kemudian disimpan pada wadah botol PE dan diberi pengawet ( $\mathrm{H} 2 \mathrm{SO} 4)$ hingga $\mathrm{pH}<2$. Beberapa data pendukung yang dikumpulkan yaitu Peta Rupa Bumi Indonesia (RBI) keluaran Badan Informasi Geospasial (BIG) skala 1:50.000 dan data arus musim barat dan musim timur, 
serta zona inti konservasi di Padaido dari dokumen data Rencana Zonasi Wilayah Pesisir dan Pulau-Pulau Kecil (RZWP3K) tahun 2015 Kabupaten Biak-Numfor yang diperoleh dari DJPRL-KKP.

\section{Analisis Spasial}

Kondisi kualitas perairan disajikan dalam data tabuler, yang masing-masing titik pengamatan memiliki koordinat geografis. Data kualitas perairan ini kemudian dinilai berdasarkan kriteria kesesuaian untuk budidaya ikan kakap dalam keramba. Parameter kualitas perairan yang memiliki nilai maksimum dan minimum yang masuk dalam julat angka sesuai kriteria untuk budidaya ikan kakap, tidak dianalisis lebih lanjut secara spasial, sehingga hanya parameter yang nilainya bervariasi yang diolah secara spasial.

Analisis spasial dilakukan dengan bantuan perangkat lunak Quantum GIS (QGIS 2.18.15). Data kualitas perairan yang berupa titik diinterpolasi dengan metode inverse distance weighted (IDW). Hasil interpolasinya berupa data raster yang kemudian dikelaskan berdasarkan kriteria sesuai dan tidak sesuai menggunakan menu raster calculator. Kriteria sesuai ditunjukkan oleh digital number 1 dan tidak sesuai dengan nilai digital number 0 . Parameter-parameter yang diinterpolasi dan dikelaskan, kemudian ditumpangsusunkan dengan operasi perkalian menggunakan raster calculator. Hasil dari seluruh perkalian tersebut merupakan hasil akhir kelas kesesuaian perairan. Khusus untuk data zona inti konservasi yang dalam bentuk vektor, terlebih dahulu digabungkan (union) dengan potongan lokasi penelitian, kemudian dikonversi ke data raster. Data raster kesesuaian ini kemudian dikonversi menjadi data vektor untuk dihitung luasannya dan dibuat tata letak (layout) peta.

\section{Analisis Daya Dukung Ekologi}

Perhitungan daya dukung ekologi perairan untuk kegiatan budidaya ikan mengacu pada estimasi jumlah limbah nitrogen $(\mathrm{N})$ yang dibuang ke lingkungan tidak boleh melebihi ambang batas yang telah ditentukan menurut KepM en LH No. 51 Tahun 2004 tentang Baku Mutu Air Laut. Baku mutu amonia untuk kehidupan biota laut adalah 0,3 mg/L. Selisih antara nilai baku mutu dan nilai awal sebelum ada budidaya (Yulianto, 2015):

$$
\ddot{A} N=N_{b m}-N_{0}
$$

di mana:

$\mathrm{N}_{\mathrm{bm}}=$ nilai nutrien baku mutu/amonia $(\mathrm{mg} / \mathrm{L})$

$\mathrm{N}_{0}=$ nilai awal nutrien/amonia $(\mathrm{mg} / \mathrm{L})$
Menurut Leung et al. (1999), nilai amonia adalah $53 \%$ dari total nitrogen ( $\mathrm{N}$ ) yang dihasilkan, sehingga untuk menghitung ÄN nitrogen adalah nilai ÄN amonia dibagi 53\%(Yulianto, 2015).

Nilai ÄN nitrogen ini adalah untuk menghitung jumlah limbah yang diperbolehkan atau tidak melebihi ambang batas, dimodifikasi dari Gowen et al. (1989) yang dikutip Barg (1992):

$$
\mathrm{TAL}=\ddot{\mathrm{A} N} \times \mathrm{Vi} \times \mathrm{D}
$$

di mana:

$\mathrm{Vi}=$ volume perairan saat surut $(\mathrm{L})$

$\mathrm{D}=$ laju pengenceran (hari) / dilution rate (day)

Flushing time merupakan waktu yang diperlukan untuk limbah tinggal di suatu perairan hingga berpindah sehingga perairan menjadi bersih (Noor, 2009; Rachmansyah, 2004). Estimasi flusing time (F) menurut Gowen et al. (1989) vide Barg (1992) adalah sebagai berikut (Sanusi, 2005; Noor, 2009):

$$
F=1 / D \text { dan } D=\frac{(V h-V i)}{T \times V h}
$$

di mana:

$\mathrm{F} \quad=$ laju pembilasan (hari)/flushing time (day)

$\mathrm{D}=$ laju pengenceran (hari)/dillution rate (day)

$\mathrm{Vh}=$ volume pada saat pasang $(\mathrm{L})$

$\mathrm{Vi}=$ volume pada saat surut $(\mathrm{L})$

$\mathrm{T}=$ periode pasang dalam satu hari

Perhitungan volume perairan pada saat surut $\left(V_{h}\right)$ dan volume pada saat pasang $\left(\mathrm{V}_{\mathrm{i}}\right)$ dihitung dengan perangkat lunak QGIS dengan tool r.volume (GRASS). Titik kedalaman pada saat surut dan pasang disiapkan dalam bentuk hasil interpolasi raster dan dipotong pada area yang sesuai untuk budidaya ikan kakap.

Kapasitas produksi yang dibolehkan (total acceptable production/TAP) merupakan jumlah ikan yang dapat diproduksi tanpa melebihi ambang batas. Nilai TAP diestimasi menggunakan rumus sebagai berikut (Soewardi, 2012):

$$
\mathrm{TAP}=\frac{\mathrm{TAL}}{\mathrm{N}_{\text {ikan }}}
$$

di mana:

TAP = total acceptable production/kapasitas produksi yang dibolehkan $(\mathrm{kg})$

$\mathrm{N}_{\text {ikan }}=$ limbah nitrogen produksi ikan (kg/ton)

Dalam penelitian ini perhitungan jumlah limbah nitrogen $\left(\mathrm{N}_{\text {ikan }}\right.$ ) yang dihasilkan dari produksi ikan merujuk pada Islam (2005). Dengan perhitungan 
sebagai berikut: pakan yang tidak dimakan adalah 20\% $\mathrm{N}$ dalam pakan adalah $6,5 \% \mathrm{P}$ (fosfat) dalam pakan adalah $1,4 \%$ N dalam ikan $3 \%$ dan P dalam ikan $1 \%$ N dan $P$ yang dihasilkan oleh ekresi dan feses dihitung dari $\mathrm{N}$ dan $\mathrm{P}$ dalam pakan yang dikonsumsi ikan dikurangi $\mathrm{N}$ dan P yang terkandung dalam ikan yang dipanen.

Pakan yang digunakan dalam perhitungan ini dengan kandungan protein $43 \%$ dan nilai konversi pakan (FCR) sebesar 1:2. KJA ukuran $3 \mathrm{~m} \times 3 \mathrm{~m} \times 3 \mathrm{~m}$ satu siklus menghasilkan 350 ekor ikan dengan bobot rata-rata $500 \mathrm{~g}$ atau sekitar $175 \mathrm{~kg}$ ikan (Trobos, 2016); sehingga untuk menghasilkan $175 \mathrm{~kg}$ ikan membutuhkan 350 $\mathrm{kg}$ pakan. Limbah fosfat dalam penelitian ini tidak dimasukan dalam perhitungan daya dukung ekologi, hanya nilai nitrogen yang dimasukan dalam perhitungan.

\section{HASIL DAN BAHASAN}

\section{Karakteristik Perairan}

Pengukuran di Teluk Urfu pada Agustus yang mewakili musim kemarau dan pada Oktober yang mewakili musim hujan, menunjukkan hasil parameter yang diukur sebagian besar masih masuk dalam batas ambang kriteria yang sesuai untuk budidaya ikan kakap. Parameter dengan kriteria sesuai tersebut adalah pH, suhu, salinitas, DO, amonia, nitrit, nitrat, fosfat, dan TSS. Hal ini kemungkinan dikarenakan kondisi Teluk Urfu yang perairannya masih alami, di mana masukan cemaran relatif sedikit. Parameter yang terlihat memiliki nilai bervariasi, sebagian masuk ambang kriteria sesuai dan sebagian lainnya masuk kriteria tidak sesuai adalah kedalaman, arus, dan kecerahan, sehingga ketiga parameter tersebut yang kemudian dianalisis secara spasial. Parameter arus dan kecerahan juga terlihat berubah saat diukur pada musim kemarau dan musim hujan.

Hasil pengukuran dan analisis laboratorium di Teluk Urfu dan di sekitar Pulau Nusi disandingkan dengan kriteria kesesuaian perairan untuk budidaya ikan kakap disajikan dalam Tabel 1.

Pada Pulau Nusi hanya diukur satu kali pada Agustus 2016. Sebagian besar parameter masuk dalam batas ambang kriteria yang sesuai untuk budidaya ikan kakap, parameter tersebut adalah $\mathrm{pH}$, suhu, salinitas, DO, amonia, nitrit, nitrat, fosfat, TSS, dan kecerahan. Parameter-parameter tersebut diasumsikan sama baik pada musim kemarau maupun musim hujan, karena di Pulau Nusi kondisinya lebih jauh dari input bahan pencemar. Parameter yang diperhitungkan untuk analisis spasial adalah parameter kedalaman, arus, dan zona inti konservasi yang diperoleh dari data RZWP3K. Parameter yang relatif berubah seiring dengan perubahan musim adalah arus, sehingga dalam analisis spasial ditambahkan arus hasil pengkuran musim barat dan musim timur dari data RZWP3K.

\section{Kesesuaian Perairan untuk Budidaya Ikan Kakap}

Perairan Teluk Urfu menempati wilayah yang sempit yaitu hanya sekitar 33 ha, tipologi perairan yang relatif tertutup, dengan kecepatan arus yang lemah. Menurut Cardia \& Lovatelli (2015), kecepatan arus $0-30 \mathrm{~cm} / \mathrm{dt}$ adalah tergolong lemah. Pada lokasi ini diperoleh area yang sesuai untuk kegiatan budidaya ikan kakap menggunakan KJA hanya 0,247 ha; luasan ini sangat kecil yaitu hanya sekitar $0,7 \%$ dari luasan Teluk Urfu. Pada saat survai lapangan di Teluk Urfu terdapat kegiatan budidaya ikan menggunakan 12 lubang KJA di dua titik. Sementara itu, hasil analisis spasial ditemukan bahwa lokasi budidaya eksisting tidak masuk dalam wilayah yang sesuai. Berdasarkan wawancara dengan DKP Biak-Numfor, ikan kerapu macan yang ditebar pada kedua KJA tersebut tidak menunjukkan pertumbuhan yang baik, diduga ikan kerapu macan kurang cocok dibudidayakan di lingkungan perairan Teluk Urfu karena kondisi arus yang sangat lemah.

Perairan sekitar Pulau Nusi di Distrik Padaido tepatnya terletak antara 3 pulau berpenghuni yaitu Pulau Nusi, Pulau Pai, dan Pulau Mioswundi, merupakan lokasi yang cukup luas dengan total area kajian pada wilayah ini yaitu sekitar 2.643 ha. Hasil analisis spasial diperoleh luas area yang sesuai untuk KJA yaitu 324,11 ha atau sekitar $12,26 \%$ dari luas total area kajian. Peta kesesuaian perairan untuk budidaya ikan kakap di Teluk Urfu dan di sekitar Pulau Nusi disajikan dalam Gambar 2.

\section{Daya Dukung Ekologi}

Perhitungan daya dukung budidaya ikan dalam KJA yang dilakukan berdasarkan input pakan dan pupuk dengan mempertimbangkan konsentrasi nutrien di awal sebelum budidaya. Dalam penelitian ini, kandungan nutrien didasarkan pada konsentrasi amonia dalam perairan. Perhitungan daya dukung lingkungan diperlukan beberapa parameter input seperti yang disajikan dalam Tabel 2.

Menurut UU No. 32 Tahun 2009 mengenai Perlindungan dan Pengelolaan Lingkungan Hidup, daya dukung lingkungan adalah kemampuan lingkungan hidup untuk mendukung kehidupan manusia, makhluk hidup lain dan keseimbangan antar keduanya. Menurut Inglis et al. yang dikutip McKindsey et al. (2006), daya dukung diklasifikasikan menjadi empat jenis, yaitu daya dukung fisik, produksi, ekologi dan sosial. McKindsey et al. (2006) menjelaskan bahwa konsep daya dukung fisik menggambarkan daerah yang secara 


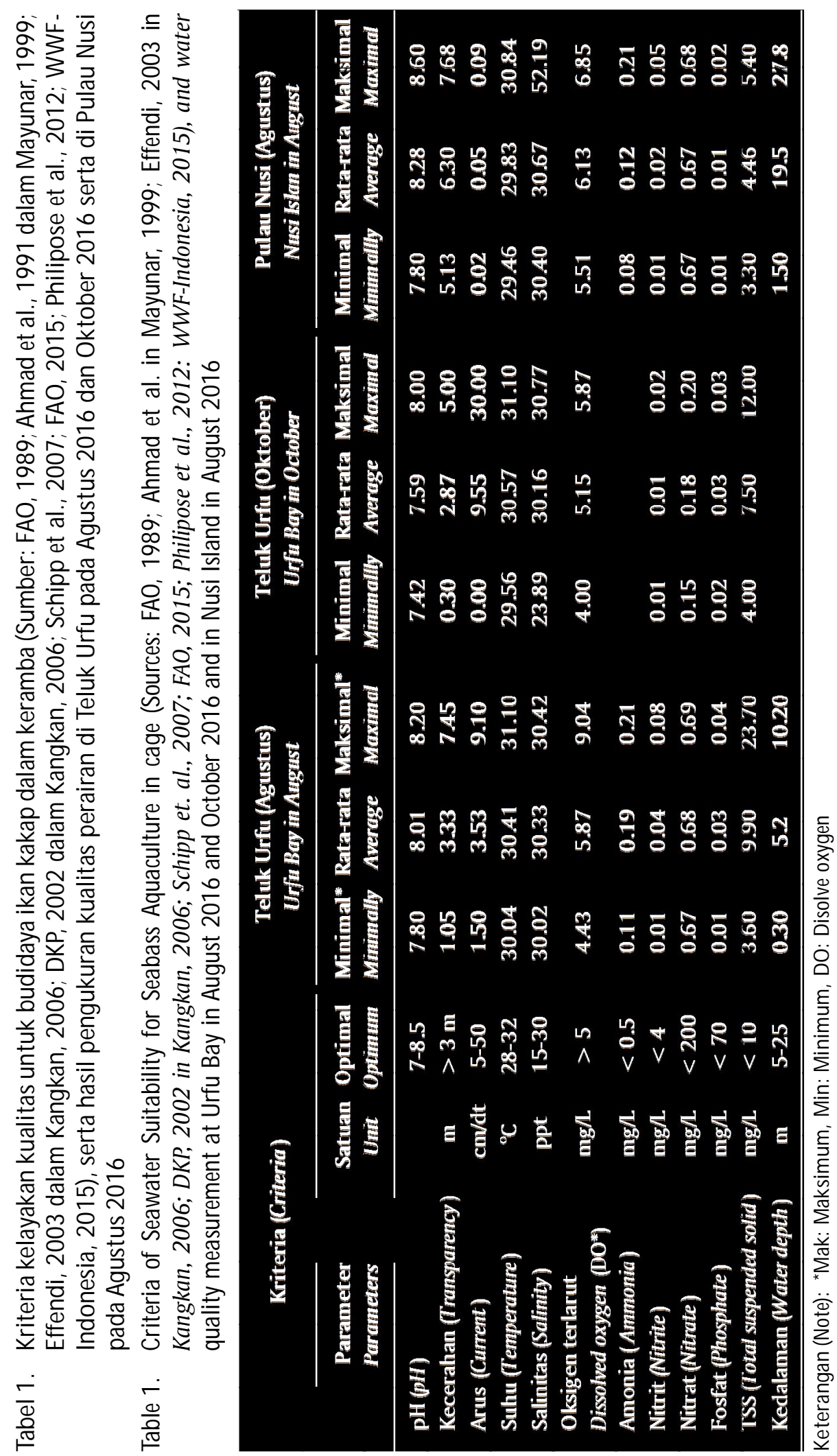




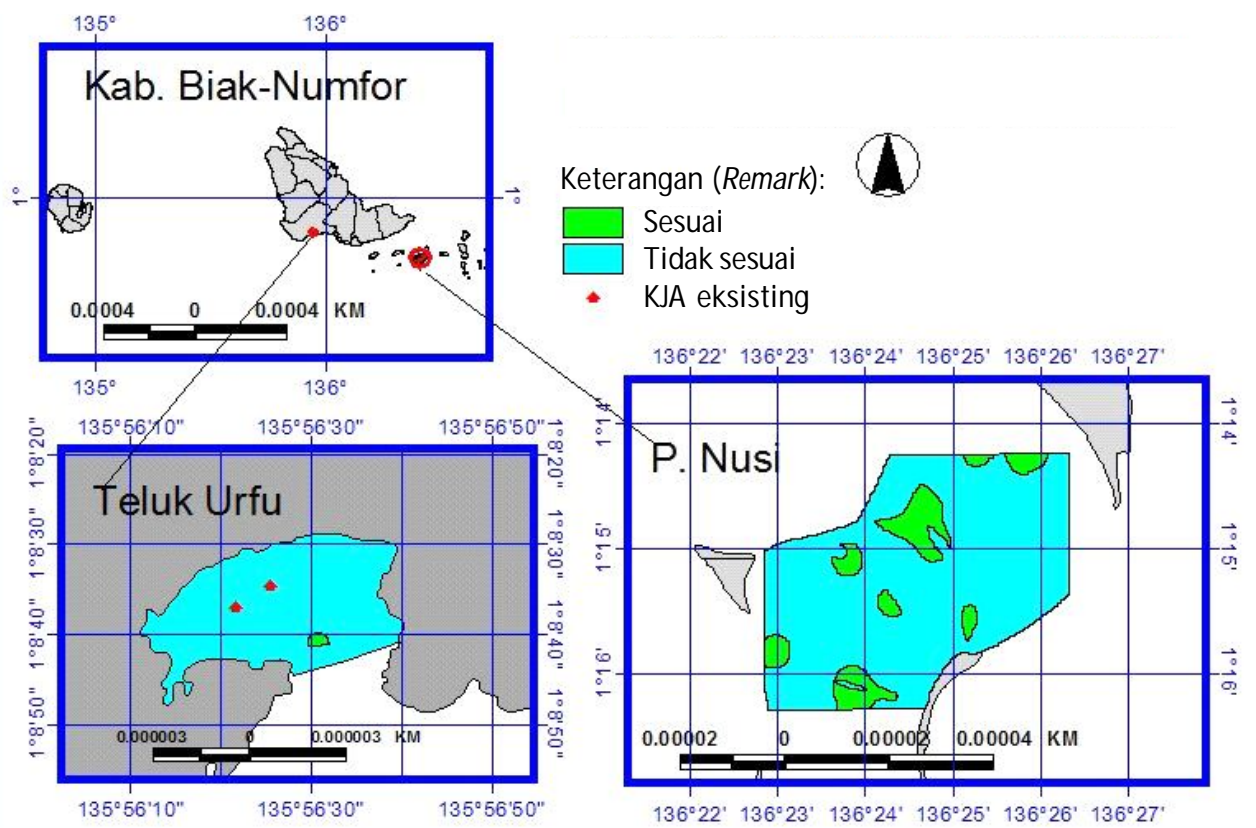

Gambar 2. Peta kesesuaian perairan budidaya ikan kakap dalam KJA.

Figure 2. Map of site suitability for seabass culture in FNC.

geografis tersedia dan secara fisik memadai untuk budidaya jenis tertentu. Daya dukung produksi merupakan tingkat produksi optimal komoditas yang dibudidayakan. Daya dukung ekologi merupakan tingkat maksimum produksi yang dimungkinkan tanpa memiliki dampak ekologi yang tidak dapat diterima. Menurut Dolmer \& Frandsen; Hoagland et al., Stead et al., Gibb yang dikutip McKindsey et al. (2006), daya dukung sosial mencakup tiga hal daya dukung tersebut di atas, merupakan timbal balik antara semua pemangku kepentingan dalam mencapai tuntutan antara kepentingan sosial ekonomi dan lingkungan.

Dayadukung fisik dan produksi menganggap bahwa pengaruh kegiatan budidaya sangat kecil terhadap ekosistem (Kurnia, 2005). Oleh karena itu, daya dukung fisik dan produksi cocok untuk kegiatan budidaya yang dilakukan tanpa penambahan pakan atau pupuk, seperti budidaya rumput laut ataupun budidaya pembesaran kerang hijau.

Pemberian pakan pada kegiatan budidaya ikan dapat berpengaruh terhadap kenaikan nutrien perairan. Keberadaan nutrien melebihi ambang batas akan menyebabkan menurunnya kualitas perairan. Nutrien utama yang memegang peranan penting adalah nitrogen (N) dan fosfat (P). Menurut Soewardi (2012), nutrien yang menjadi faktor pembatas pada perairan laut biasanya adalah nitrogen (N). Ackefors \& Enell (1990) yang dikutip Islam (2005) menyatakan bahwa sistem budidaya laut dalam KJA tidak menggunakan pupuk baik organik maupun non-organik dengan $\mathrm{N}$

Tabel 2. Parameter input untuk menghitung daya dukung lingkungan KJA

Table 2. Input parameters for calculating environmental carrying capacity of FNC

\begin{tabular}{lccc}
\hline \multicolumn{1}{c}{$\begin{array}{c}\text { Parameter } \\
\text { Parameters }\end{array}$} & $\begin{array}{c}\text { Satuan } \\
\text { Unit }\end{array}$ & $\begin{array}{c}\text { Teluk Urfu } \\
\text { Urfu Bay }\end{array}$ & $\begin{array}{c}\text { Pulau Nusi } \\
\text { Nusi Island }\end{array}$ \\
\hline Luas kesesuaian (LK) / Suitable area & $\mathrm{m}^{2}$ & 2,470 & $3,241,100$ \\
Luas unit budidaya (LU) / Area for culture & $\mathrm{m}^{2}$ & 9 & 9 \\
N awal (amonia) / Initial N (ammonia) & $\mathrm{mg} / \mathrm{L}$ & 0.19 & 0.12 \\
N BM (amonia) / N quality standard (ammonia) & $\mathrm{mg} / \mathrm{L}$ & 0.3 & 0.3 \\
$\Delta \mathrm{N}$ amonia & $\mathrm{mg} / \mathrm{L}$ & 0.11 & 0.18 \\
$\Delta \mathrm{N}$ nitrogen & $\mathrm{mg} / \mathrm{L}$ & 0.2 & 0.34 \\
T (periode pasang surut) / T (tide period) & Hari (Day) & 0.5 & 0.5 \\
\hline
\end{tabular}


dan $\mathrm{P}$ yang tinggi, akan tetapi menggunakan pakan yang tinggi $N$. Zat pembatas ini yang diperhitungkan dalam menentukan daya dukung lingkungan, walaupun keberadaannya sedikit namun dapat menggangu produktivitas perairan. Nitrogen dalam air terbagi menjadi empat bentuk, yaitu nitrat, nitrit, amonia, dan nitrogen organik. Dalam penelitian ini hanya amonia yang akan dijadikan acuan dalam perhitungan daya dukung lingkungan (dalam hal ini daya dukung ekologi). Konsentrasi maksimum amonia ditentukan dengan mengacu kepada KepMen. LH No. 51 Tahun 2004 tentang Baku Mutu Air Laut untuk kehidupan biota laut adalah $0,3 \mathrm{mg} / \mathrm{L}$.

Periode pasang surut di Biak adalah dua kali dalam sehari dengan jarak pasang tertinggi dan surut terendah adalah 1,8 m berdasarkan data dari BIG. Kandungan nutrien sebelum ada aktivitas budidaya diambil konsentrasi amonia rata-rata pada area yang sesuai untuk budidaya KJA.

Luas unit Budidaya diasumsikan adalah KJA kotak $9 \mathrm{~m}$ persegi atau KJA dengan ukuran $3 \mathrm{~m} \times 3 \mathrm{~m}$. Perhitungan daya dukung fisik lebih sederhana, faktor yang harus dipertimbangkan adalah kegiatan lain di sekitar lokasi, direkomendasikan hanya 10\%dari total daya dukung fisik atau luas wilayah yang sesuai untuk KJA (Hidayah \& Wardhani, 2015; So ewardi, 2012), seperti yang disajikan dalam Tabel 3.

Hasil perhitungan jumlah $\mathrm{N}$ dan Pyang dibuang ke lingkungan disajikan dalam Tabel 4.

Kapasitas produksi yang dibolehkan (TAP) yang kemudian dikonversi menjadi jumlah unit lubang KJA yang diperbolehkan disajikan dalam Tabel 5.

Hasil perhitungan daya dukung fisik lebih besar daripada daya dukung ekologi. Jika mengacu pada perhitungan daya dukung ekologi untuk budidaya ikan dalam KJA, untuk Teluk Urfu tidak direkomendasikan adanya budidaya ikan. Hasil perhitungan kapasitas produksi yang dibolehkan (TAP) adalah $12,75 \mathrm{~kg}$ sedangkan total nutrien yang dibuang ke lingkungan dalam satu kali siklus adalah $17,5 \mathrm{~kg}$ atau lebih besar dari nilai TAP. Saat ini di Teluk Urfu telah dipasang
KJA bentuk kotak 12 lubang, sehingga untuk Teluk urfu sebaiknya tidak dipasang lagi KJA mengingat daya dukung lingkungannya yang kurang memadai.

Daya dukung ekologi di Pulau Nusi untuk budidaya ikan dalam KJA adalah 158 unit atau 1.422 meter persegi, jika per unit mampu produksi $175 \mathrm{~kg}$ atau 0,175 ton maka bisa menghasilkan produksi sekitar 27,65 ton per siklus. Kondisi saat ini belum terdapat KJA yang terpasang di lokasi ini, sehingga pengembangannya masih sangat luas.

Dari estimasi perhitungan daya dukung ekologi ini, Pulau Nusi memiliki luasan area yang cukup besar untuk dikembangkan. Pengembangan budidaya ikan sebaiknya mampu memproduksi ikan minimal sejumlah 4 ton atau 8 ton per bulan. Hal ini berkaitan dengan tonnase kapal angkut ikan yang biasanya memuat 4 ton atau 8 ton ikan dalam sekali angkut.

DKP (2002) yang dikutip Cocon et al. (2016) menyatakan bahwa daya dukung perairan untuk pengembangan budidaya laut sistem KJA berdasarkan persentase kapasitas perairan yaitu seluas $20 \%$ dari total luas perairan yang sesuai. Namun penentuan $20 \%$ dari total luasan yang sesuai kemungkinan kurang cocok diterapkan untuk area studi yang dilaksanakan oleh Cocon et al. (2016) di kawasan perairan Teluk Ekas Kabupaten Lombok Timur. Cocon et al. (2016) menghitung dari $20 \%$ area yang sesuai dihasilkan kapasitas unit KJA yang dapat ditampung, yaitu sekitar 16.222 unit. Cocon et al. (2016) kemudian melanjutkan dengan menghitung nilai indeks keberlanjutan melalui pendekatan dengan metode Multidimensional Scalling dengan teknik ordinasi Rapfish. Hasil analisis keberlanjutan tersebut masuk dalam kategori "kurang berkelanjutan".

Hasil penelitian lainnya untuk penghitungan daya dukung dari pendugaan beban limbah nitrogen (amonia), diperoleh luasan kurang dari 0,05\%dari area yang diteliti (sesuai). Seperti penelitian yang dilakukan oleh Bramana (2015), penghitungan daya dukung lingkungan untuk budidaya ikan kerapu dalam KJA di Pulau Semak Daun Kepulauan Seribu, hasil

Tabel 3. Rekomendasi daya dukung fisik (DDF) KJA

Table 3. Physical carrying capacity recommendation (FCC) for FNC

\begin{tabular}{lccc}
\hline \multicolumn{1}{c}{$\begin{array}{c}\text { Parameter } \\
\text { Parameters }\end{array}$} & $\begin{array}{c}\text { Satuan } \\
\text { Unit }\end{array}$ & $\begin{array}{c}\text { Teluk Urfu } \\
\text { Urfu Bay }\end{array}$ & $\begin{array}{c}\text { Pulau Nusi } \\
\text { Nusi Island }\end{array}$ \\
\hline $\begin{array}{l}\text { Daya dukung fisik (DDF) } \\
\begin{array}{l}\text { Physycal carrying capacity (CCF) } \\
\text { Rekomendasi (10\%DDF) } \\
\text { Reccomended (10\% of FCC) }\end{array}\end{array}$ & Unit & 274 & 360,122 \\
\hline
\end{tabular}


Tabel 4. Nutrien yang dihasilkan dari budidaya ikan dengan KJA (adopsi dari Islam, 2005)

Table 4. Nutrien produced by fish culture by FNC (adopted from Islam, 2005)

\begin{tabular}{|c|c|c|c|c|c|c|}
\hline \multirow{3}{*}{$\begin{array}{l}\text { Parameter } \\
\text { Parameters }\end{array}$} & \multirow{3}{*}{$\begin{array}{l}\text { Nilai } \\
\text { Value }\end{array}$} & \multicolumn{2}{|c|}{ Pakan } & \multicolumn{2}{|c|}{ Ikan } & \multirow{3}{*}{$\begin{array}{c}\text { Satuan } \\
\text { Unit }\end{array}$} \\
\hline & & $6.50 \%$ & $1.40 \%$ & $3 \%$ & $1 \%$ & \\
\hline & & $\mathbf{N}$ & $\mathbf{P}$ & $\mathbf{N}$ & $\mathbf{P}$ & \\
\hline FCR & 1:02 & & & & & \\
\hline Jumlah Pakan & 350 & & & & & $\mathrm{~kg}$ \\
\hline 80\%pakan dikonsumsi ikan & 280 & 18.2 & 3.92 & & & $\mathrm{~kg}$ \\
\hline Panen ikan & 175 & - & - & 5.25 & 1.75 & $\mathrm{~kg}$ \\
\hline Dibuang ekresi dan feses & 105 & 12.95 & 2.17 & & & $\mathrm{~kg}$ \\
\hline 20\%pakan tidak dimakan & 70 & 4.55 & 0.98 & & & $\mathrm{~kg}$ \\
\hline Total yang dibuang ke lingkungan & 175 & 17.5 & 3.15 & & & $\mathrm{~kg}$ \\
\hline
\end{tabular}

Tabel 5. Hasil perhitungan daya dukung pada lingkungan KJA

Table 5. The result of calculation of environmental carrying capacity in FNC

\begin{tabular}{|c|c|c|c|}
\hline $\begin{array}{l}\text { Parameter } \\
\text { Parameters }\end{array}$ & $\begin{array}{l}\text { Satuan } \\
\text { Unit }\end{array}$ & $\begin{array}{l}\text { Teluk Urfu } \\
\text { Urfu Bay }\end{array}$ & $\begin{array}{l}\text { Pulau Nusi } \\
\text { Nusi Island }\end{array}$ \\
\hline$\Delta N$ Nitrogen & $\mathrm{mg} / \mathrm{L}$ & 0.2 & 0.34 \\
\hline $\begin{array}{l}\text { Volume saat surut } \\
\text { Volume at low tide }\end{array}$ & L & $13,813.103$ & 637.80 .318 .622 \\
\hline $\begin{array}{l}\text { Voulme saat pasang } \\
\text { Volume at high tide }\end{array}$ & L & 17.253 .986 & 679.96.316.109 \\
\hline $\begin{array}{l}\text { D (laju pengenceran) } \\
\text { Dilution rate (D) }\end{array}$ & $\begin{array}{l}\text { Hari } \\
\text { Day }\end{array}$ & 0.399 & 0.124 \\
\hline $\begin{array}{l}\text { F (Laju pembilasan) } \\
\text { F (Flushing rate) }\end{array}$ & & 2.5 & 8.1 \\
\hline $\begin{array}{l}\text { D (laju pengenceran selama masa pemeliharaan } 180 \text { hari) } \\
\text { D (Dilution rate during periods of culture } 180 \text { days) }\end{array}$ & $\begin{array}{l}\text { Hari } \\
\text { Day }\end{array}$ & 71.79 & 22.3 \\
\hline $\begin{array}{l}\text { Jumlah nutrien yang dibolehkan } \\
\text { TAL ( Total acceptable loading) }\end{array}$ & $\mathrm{kg}$ & 223 & 484,042 \\
\hline $\begin{array}{l}\text { Kapasitas produksi yang dibolehkan } \\
\text { TAP (Total acceptable production) }\end{array}$ & $\mathrm{kg}$ & 12.75 & $27,659.54$ \\
\hline $\begin{array}{l}\text { Target panen } \\
\text { Harvest target }\end{array}$ & $\mathrm{kg}$ & 175 & 175 \\
\hline $\begin{array}{l}\text { Jumlah KJA } \\
\text { Number of FNC }\end{array}$ & Unit & 0 & 158 \\
\hline
\end{tabular}

penghitungan daya dukung dari pendugaan beban limbah nitrogen (amonia) budidaya dan aktivitas antropogenik yaitu 90 unit ( $3 \mathrm{~m} \times 3 \mathrm{~m}$ ) KJA atau dalam jumlah produksi mencapai 97 ton ikan, dengan luas area penelitian adalah 315,19 ha.

Penelitian Noor (2009) di Teluk Tamiang, Kabupaten Kotabaru diperoleh luas perairan yang sesuai untuk budidaya ikan kerapu mencapai 385 ha. Berdasarkan perhitungan beban limbah (tingkat mutu amonia $0,3 \mathrm{mg} / \mathrm{L}$ ) produksi optimal yang diijinkan adalah 18,8 ton ikan atau 80 lubang KJA ukuran $3 \mathrm{mx}$ $3 \mathrm{~m} \times 2,5 \mathrm{~m}$ atau sekitar 1.800 meter persegi, sehingga menempati sekitar $0,047 \%$ dari area yang sesuai untuk budidaya ikan. 


\section{KESIMPULAN}

Area yang potensial untuk pengembangan budidaya laut utamanya ikan kakap putih (Lates calcarifer) di Pulau Nusi adalah 324,11 ha; sedangkan untuk Teluk Urfu areanya sangat kecil yaitu 0,247 ha.

Di Teluk Urfu tidak direkomendasikan untuk budidaya ikan mengingat daya dukung lingkungan yang kurang memadai.

Lokasi budidaya laut yang pengembangannya masih sangat luas adalah di Pulau Nusi, yaitu 158 lubang KJA atau menempati area 1.422 meter persegi atau $0,04 \%$ dari area yang sesuai untuk budidaya ikan kakap putih.

\section{UCAPAN TERIMA KASIH}

Ucapan terima kasih kepada Pusat Penelitian dan Pengembangan Perikanan (Puslitbang Perikanan), Badan Penelitian dan pengembangan Perikanan dan Kelautan, Kementerian Kelautan dan Perikanan (KKP) yang telah membiayai penelitian ini melalui DIPA T.A. 2016. Ucapan terima kasih kepada rekan peneliti di Puslitbang Perikanan atas dukungannya. Serta ucapan terima kasih kepada Bapak Muta Ali Khalifa (Universitas Sultan Ageng Tirtayasa).

\section{DAFTAR ACUAN}

Akmal, S.G. (2011). Pembenihan dan pembesaran ikan kakap putih (Lates calcarifer) Di Balai Besar Pengembangan Budidaya Laut, Lampung. Laporan Praktik Kerja Lapangan. Program Keahlian Teknologi Produksi dan Manajemen Perikanan Budidaya. Program diploma. IPB.

Barg, U.C. (1992). Guidelines for the promotion of environmental management of coastal aquaculture development (based on a review of selected experiences and concepts). FAO Fisheries Technical Paper, No. 328. Rome. FAO, 122 pp.

Bramana, A. (2015). Analisis keberlanjutan usaha keramba jaring apung dengan pendekatan daya dukung lingkungan dan sosial ekonomi (Studi Kasus: Kelompok sea farming perairan Pulau Semak Daun Kepulauan Seribu DKI Jakarta). Tesis. Sekolah Pascasarjana Institut Pertanian Bogor; Bogor. http:/ /repository.ipb.ac.id/handle/123456789/77413.

Cardia, F. \& Lovatelli, A. (2015). Aquaculture Operation in Floating Net Cages A Field Hanbook. FAO Fisheries and Aquaculture Technical Paper No. 593. Rome, FAO, $152 \mathrm{pp}$.

Cocon, Yusuf, M., \& Anggoro, S. (2016). Kajian daya dukung kapasitas perairan dan status keberlanjutan dimensi ekologi pada kawasan sub zona pengembangan budidaya laut sistem karamba jaring apung (KJA) di perairan Teluk Ekas,
Kabupaten Lombok Timur, NTB. Seminar Nasional Perikanan dan Kelautan 2016. Program Studi Budidaya Perairan Fakultas Pertanian Universitas Lampung. http://semnas.fp.unila.ac.id/index.php/ semnas/Semnaskan/paper/viewFile/67/12.

FAO. (1989). Site selection criteria for marine finfish netcage culture in Asia. http://www.fao.org/3/contents/c64db3a7-9ff0-5c7b-bf4c-d9bc657ab35d/ AC262E00.htm

FAO. (2010). Aquaculture development. 4. Ecosystem approach to aquaculture. FAO Technical Guidelines for Responsible Fisheries. No. 5, Suppl. 4. Rome. FAO, $53 \mathrm{pp}$.

FAO. (2015). Aquaculture operation in floating net cages a field handbook. Eds Cardia Francesco and Lovateli Alessandro. Food and Agriculture Organization of the United Nations. Rome, $151 \mathrm{pp}$.

FAO (2018). Cultured aquatic species information programme Lates calcarifer (Block, 1790). Fisheries and Aquaculture Department. http:// www.fao.org/fishery/culturedspecies/ Lates_calcarifer/en.

Hidayah, Z. \& Wardhani, M.K. (2015). Analisa kesesuaian dan daya dukung lingkungan untuk budidaya laut di perairan Kabupaten Situbondo dan Banyuwangi. Neptunus Jurnal Kelautan, 20(1), 4050.

Islam, Md.S. (2005). Nitrogen and phosphorus budget in coastal and marine cage aquaculture and impacts of effluent loading on ecosystem: review and analysis towards model development. Marine Polution Bulletin, 50, 48-61.

Kangkan, A.L. (2006). Studi Penentuan Lokasi Untuk Pengembangan Budidaya Laut Berdasarkan Parameter Fisika, Kimia Dan Biologi Di Teluk Kupang, Nusa Tenggara Timur. Tesis S2. Program Studi Magister Manajemen Sumberdaya Pantai. Universitas Diponegoro Semarang.

Kurnia, R. (2005). Penentuan daya dukung lingkungan pesisir. Makalah Falsafah Sains Sekolah Pascasarjana. Institut Pertanian Bogor.

Leung, K.M.Y., Chu, J.C.W., \& Wu, R.S.S. (1999). Nitrogen budgets for the areolated grouper Epinephelus areolatus cultured under laboratory conditions and in open-sea cages. Marine Ecology Progress Series, 186, 271-281.

Mayunar. (1999). Produktivitas Beberapa Jenis Ikan Laut yang Dibudidaya dalam Keramba Jaring Apung. Oseana, Volume XXIV, Nomor 2, 1999 : 21-26. http:/ loseanografi.lipi.go.id/dokumen/oseana_xxiv(2)2126.pdf.

McKindsey, C.W., Thetmeyer, H., Landry, T., \& Silvert, W. (2006). Review of recent carrying capacity 
models for bivalve culture and recommendations for research and management. Aquaculture, 261, 451-462. http://www.ecasa.org.uk/Documents/ Silvert_Aquaculture2006.pdf.

Noor, A. (2009). Model pengelolaan kualitas lingkungan berbasis daya dukung (carring capacity) perairan teluk bagi pengembangan budidaya keramba jaring apung ikan kerapu (Studi kasus di Teluk Tamiang, Kabupaten Kotabaru Provinsi Kalimantan Selatan). Disertasi S3. IImu Pengelolaan Sumberdaya Pesisir dan Lautan. Institut pertanian Bogor.

Philipose, K.K., Loka, J., Shrama, S.R.K., \& Danmodaran, D. (2012). Open sea cage culture. Central Marine Fisheries Research Institute, Karwar Research Centre, Karnataka, India.

Priyono, A., Slamet, B., Aslianti, T., Setiadharma, T., Setyadi, I., Permana, I G.N., \& Setiawibawa, G. (2013). Pembesaran kakap putih, seabass (Lates calcarifer Bloch) di tambak dengan pemberian pakan pelet kandungan protein berbeda untuk calon induk melaui seleksi pertumbuhan. Konferensi Akuakultur Indonesia, hlm. 245-251.

Rachmansyah. (2004). Analisis daya dukung lingkungan perairan Teluk Awarange Kabupaten Barru, Sulawesi Selatan bagi pengembangan budidaya bandeng dalam keramba jaring apung. Disertasi S3. IImu Pengelolaan Sumberdaya Pesisir dan Lautan. Institut Pertanian Bogor.

Sanusi, H.S., Kaswadji, R.F., Nurjaya, I.W., \& Rafni, R. (2005). Kajian kapasitas asimilasi beban pencemaran organik dan anorganik di perairan Teluk Jobokuto Kabupaten Jepara, Jawa Tengah.
Jurnal IImu-IImu Perairan dan Perikanan Indonesia, 12(1), 9-16.

Schipp, G., Bosmans, J., \& Humphrey, J. (2007). Nortern territory barramundi farming handbook. Department of Primary Industry, Fisheries and Mines, Darwin Aquaculture Centre. ISBN: 07245 4727 4. https://dpir.nt.gov.au/ data/assets/pdf file/ 0011/233696/nt_barra_farming_handbook_online_ 1107.pdf.

Simorangkir, E. (2017). Budidaya kakap putih digenjot, produksi ditarget 2.415 ton/tahun. https:// finance.detik.com/berita-ekonomi-bisnis/3451545/ budidaya-kakap-putih-digenjot-produksi-ditarget2415-tontahun.

Soewardi, K. (2012). Carrying capacity open water with respect to fosfat $(\mathrm{P})$. bahan mata kuliah pengelolaan sumber daya perairan. Sekolah Pascasarjana. Institut Pertanian Bogor.

Trobos. (2016). KJA Aquatec dukung budidaya laut. http://www.trobos.com/detail-berita/2016/11/23/ 86/8153/aquatec-dukung-penelitian-di-bbpbllampung.

WWF-Indonesia. (2015). Seri Panduan Perikanan Skala Kecil: Budidaya Ikan Kakap Putih Di Karamba Jaring Apung Dan Tambak. http://awsassets.wwf.or.id/ downloads/bmp_budidaya_ikan_kakap_putih_ 2015.pdf

Yulianto, H., Atiastari, N., \& Damai, A.A. (2015). Analisis daya dukung perairan pahawang untuk kegiatan budidaya sistem keramba jaring apung. Aquasains, hlm. 259-263. 